\title{
BIOCHEMICAL CHANGES OCCURRING DURING SPORULATION OF BACILLUS CEREUS ${ }^{1}$
}

\author{
Inhibition of Sporulation By $\alpha$-Picolinic AcID $^{2}$
}

\author{
KRISHNAMURTY G. GOLLAKOTA ${ }^{3}$ AND H. ORIN HALVORSON \\ Department of Microbiology, University of Illinois, Urbana, Illinois
}

Received for publication February 25, 1959

The effects of nutritional and environmental conditions on sporulation and the properties of the spore have been extensively studied with the hope that these may provide a clue to the mechanism of dormancy and resistance of the bacterial endospore. However, there is no general agreement and our knowledge of these is still limited. The extensive literature dealing with the various aspects of sporogenesis has been reviewed by Cook (1932); Knaysi (1948); Williams (1952); Stedman (1956); and Halvorson (1957b).

Buchner (1890) showed that Bacillus anthracis may be kept indefinitely in the vegetative stage by periodic transfer into a fresh medium. He further observed that when vegetative cells of this organism were incubated in distilled water under conditions suitable for sporulation, spores were formed sooner than in the original culture. Schreiber (1896), who confirmed and extended these observations, concluded that spores were never formed under conditions of continuous active growth and that sudden hindrance of growth following good nutrition caused immediate and complete sporulation.

Most of the above studies were carried out before the discovery by Powell (1953) of dipicolinic acid as a constituent of the spores of Bacillus megaterium. Dipicolinic acid is present in all the bacterial spores examined and is absent from the homologous vegetative forms. Much evidence has since been accumulated to warrant dipicolinic acid being assigned a possible role in the dormancy and resistance of the bacterial spore (Perry and Foster, 1954; Collier and Murty,

${ }^{1}$ Referred to as Bacillus cereus var. terminalis in earlier publications.

2 This work was presented in part at The Society of American Bacteriologists' meeting at Chicago, Illinois, April 27 to May 2, 1958 and supported by a grant from the Office of Naval Research.

${ }^{3}$ Previously publishing under the name of G. G. Krishna Murty or G. G. K. Murty.
1957; Murty and Halvorson, 1957a; Harrell et al. 1957; Collier and Nakata, 1958; and Harrell, 1958). The present study of the effects of $\alpha$-picolinic acid on growth and sporulation of Bacillus cereus type $\mathrm{T}$ was undertaken with the hope that it might provide valuable information regarding sporogenesis.

\section{MATERIALS AND METHODS}

Test organism. Stock cultures of the test organism $B$. cereus type $T$ were allowed to sporulate on agar slants and then kept refrigerated. These were inoculated into sterile distilled water to give a suspension having a turbidity of 180 to 200 Klett units. This suspension was heated for 30 min at $80 \mathrm{C}$ to kill vegetative cells and $0.2 \mathrm{ml}$ of it was used to inoculate $100 \mathrm{ml}$ of the medium.

Cultural methods. Stock solutions of phosphate, yeast extract, glucose, calcium chloride, and other minerals were prepared individually. The solutions were autoclaved separately and mixed to give a medium of the following composition: $\mathrm{FeSO}_{4} \cdot 7 \mathrm{H}_{2} \mathrm{O}, 0.00005$ per cent; $\mathrm{CuSO}_{4} \cdot 5 \mathrm{H}_{2} \mathrm{O}$, 0.0005 per cent; $\mathrm{ZnSO}_{4} \cdot 7 \mathrm{H}_{2} \mathrm{O}, 0.0005$ per cent; $\mathrm{MnSO}_{4} \cdot \mathrm{H}_{2} \mathrm{O}, 0.005$ per cent; $\mathrm{MgSO}_{4}, 0.02$ per cent; $\mathrm{CaCl}_{2} \cdot 2 \mathrm{H}_{2} \mathrm{O}, 0.008$ per cent; $\mathrm{K}_{2} \mathrm{HPO}_{4}, 0.05$ per cent; $\left(\mathrm{NH}_{4}\right)_{2} \mathrm{SO}_{4}, 0.2$ per cent; yeast extract, 0.2 per cent; and glucose 0.1 per cent. The cultures were incubated at $30 \mathrm{C}$ on a reciprocating shaker.

An active culture was prepared according to the method of Collier (1957), which consisted mainly in periodic transfer into a fresh medium. Routinely 4 such transfers were made.

Growth. Growth was determined by measuring the turbidity of cultures with a Klett-Summerson photoelectric colorimeter using a no. 42 blue filter (400 to $465 \mathrm{~m} \mu$ ). Occasionally the total number of. viable cells was evaluated by plating on nutrient agar.

Sporulation. Sporulation was detected by microscopic examination of stained smears. The 
TABLE 1

Effect of $\alpha$-picolinic acid on building up an active culture of Bacillus cereus at $30 \mathrm{C}$

\begin{tabular}{|c|c|c|c|c|}
\hline \multirow{2}{*}{ Culture } & \multicolumn{2}{|c|}{ Control } & \multicolumn{2}{|c|}{$\begin{array}{c}\text { Medium Contain- } \\
\text { ing } \alpha \text {-Picolinic } \\
\text { Acid }(1.2 \times \\
\left.10^{-3} \mathrm{M}\right)\end{array}$} \\
\hline & $\begin{array}{c}\text { Klett } \\
\text { reading }\end{array}$ & $\mathrm{pH}$ & $\begin{array}{l}\text { Klett } \\
\text { reading }\end{array}$ & $\mathrm{pH}$ \\
\hline Starter. & 150 & 6.3 & 180 & 5.9 \\
\hline Transfer: & & & & \\
\hline $1 \ldots \ldots$ & 240 & 5.4 & 240 & 5.4 \\
\hline 2 . & 280 & 5.4 & 270 & 5.4 \\
\hline $3^{*}$. & 290 & 5.1 & 270 & 5.1 \\
\hline
\end{tabular}

* Centrifuged aseptically to yield control cells, control supernatant, $\alpha$-picolinic grown cells, and $\alpha$-picolinic medium. The control cells were suspended in $\alpha$-picolinic supernatant and the $\alpha$ picolinic grown cells were suspended in control supernatant and incubated on a shaker at $30 \mathrm{C}$.

\begin{tabular}{l|l|c|c|c}
\hline & \multicolumn{3}{|c}{ After Incubation for $18 \mathrm{Hr}$} \\
\cline { 2 - 5 } & $\begin{array}{c}\text { Klett } \\
\text { read- } \\
\text { ing }\end{array}$ & $\begin{array}{c}\text { Viable } \\
\text { cells/ml }\end{array}$ & $\begin{array}{c}\text { Heat } \\
\text { stable } \\
\text { cells/ml }\end{array}$ & $\mathrm{pH}$ \\
\hline $\begin{array}{c}\alpha \text {-Picolinic grown } \\
\text { cells in control } \\
\text { supernatant.... }\end{array}$ & 550 & $2.1 \times 10^{8}$ & $3 \times 10^{8}$ & 7.9 \\
$\begin{array}{c}\text { Control cells in } \\
\alpha \text {-picolinic su- }\end{array}$ & 425 & $7 \times 10^{6}$ & $<10^{3}$ & 5.3 \\
\hline pernatant...... & 425 & & \\
\hline
\end{tabular}

TABLE 2

Growth and sporulation of an active culture of Bacillus cereus at $30 \mathrm{C}$ Control

\begin{tabular}{|c|c|c|c|c|}
\hline $\begin{array}{l}\text { Time of } \\
\text { sampling }\end{array}$ & $\begin{array}{c}\text { Klett } \\
\text { reading }\end{array}$ & $\mathrm{pH}$ & $\begin{array}{l}\text { Viable } \\
\text { cells/ml }\end{array}$ & $\begin{array}{l}\text { Heat stable } \\
\text { cells/ml }\end{array}$ \\
\hline$h r$ & & & & \\
\hline 0 & 85 & 7.05 & $1.16 \times 10^{7}$ & $<10^{2}$ \\
\hline 1 & 155 & 6.5 & $4.4 \times 10^{7}$ & $<10^{2}$ \\
\hline 2 & 260 & 5.05 & $1.26 \times 10^{8}$ & $<10^{2}$ \\
\hline 3 & 320 & 5.3 & $1.5 \times 10^{8}$ & $<10^{3}$ \\
\hline 18 & 550 & 8.3 & $1.9 \times 10^{8}$ & $2.6 \times 10^{8}$ \\
\hline
\end{tabular}

number of spores was determined by plating the sample after heating it for $30 \mathrm{~min}$ at $80 \mathrm{C}$.

$p H$. The $\mathrm{pH}$ of the samples was determined with a Beckman $\mathrm{pH}$ meter.
Analogues. The test compounds were obtained from chemical firms with the exception of dipicolinic acid which was kindly supplied by Dr. T. O. Soine, University of Minnesota. Stock solutions of the analogues were prepared in distilled water. These were sterilized after adjusting the $\mathrm{pH}$ to 7.2 to 7.5 with sodium hydroxide or hydrochloric acid, stored in the deep freeze, and later added aseptically to the cultures to give the desired concentrations.

To study the effect of a compound on sporulation only it was added to an active culture. To study the effect on germination, growth, and sporulation, the compound was added to a medium inoculated with a heat shocked spore suspension.

\section{RESULTS}

Since preliminary experiments showed small amounts of exogenous dipicolinic acid have no effect on germination, growth, and sporulation of the test organism, it seemed interesting to study the effects of analogues of dipicolinic acid on the growth and sporulation of this organism.

Preliminary experiments showed that $\alpha$-picolinic acid inhibited sporulation without inhibiting growth or germination. Though the minimum inhibitory concentration was $8 \times 10^{-4} \mathrm{M}$, the concentration of $\alpha$-picolinic acid routinely used was $1.2 \times 10^{-3} \mathrm{M}$. To study the effect of $\alpha$-picolinic acid on germination and growth, a large volume of the medium was inoculated with heat shocked spores. To a part, $\alpha$-picolinic acid was added and the rest was used for control. Both cultures were incubated on a shaker at $30 \mathrm{C}$. Active cultures were prepared from these by transferring both at the same intervals, each into the corresponding fresh medium. Periodically the turbidity, $\mathrm{pH}$, stain, and viable counts of both the cultures were determined. From the results (table 1) it will be seen that there was no significant difference between these two cultures at any time during these transfers. When the final cultures reached maximum growth, they were centrifuged separately under aseptic conditions to yield normal cells and normal supernatant, $\alpha$-picolinic grown cells and $\alpha$-picolinic supernatant. The normal cells were then suspended in the $\alpha$-picolinic supernatant and the $\alpha$-picolinic grown cells in the normal supernatant and both suspensions were incubated at $30 \mathrm{C}$ on a shaker. When examined at the end of $18 \mathrm{hr}$, it was found 
TABLE 3

Effect of time of addition of $\alpha$-picolinic acid on growth and sporulation of an active culture of Bacillus cereus at $30 \mathrm{C}$

Concentration of $\alpha$-picolinic acid $\left(1.2 \times 10^{-3} \mathrm{M}\right)$

\begin{tabular}{|c|c|c|c|c|c|c|c|c|c|c|c|c|c|}
\hline \multirow{3}{*}{$\begin{array}{c}\text { Time of Ad- } \\
\text { dition of } \\
\alpha-\text { Picolinic } \\
\text { Acid }\end{array}$} & \multicolumn{13}{|c|}{ Time of Sampling after Addition of $\alpha$-Picolinic Acid } \\
\hline & \multicolumn{4}{|c|}{$1 \mathrm{Hr}$} & \multicolumn{5}{|c|}{$2 \mathrm{Hr}$} & \multicolumn{4}{|c|}{$18 \mathrm{Hr}$} \\
\hline & \begin{tabular}{|c} 
Klett \\
reading
\end{tabular} & $\mathrm{pH}$ & $\begin{array}{c}\text { Viable } \\
\text { cells/ml }\end{array}$ & $\begin{array}{c}\text { Heat } \\
\text { stable } \\
\text { cells } \\
\text { ml }\end{array}$ & $\begin{array}{c}\text { Klett } \\
\text { reading }\end{array}$ & $\mathrm{pH}$ & & $\begin{array}{l}\text { Viable } \\
\text { ells/ml }\end{array}$ & $\begin{array}{c}\text { Heat } \\
\text { stable } \\
\text { cells/ } \\
\text { ml }\end{array}$ & $\begin{array}{c}\text { Klett } \\
\text { reading }\end{array}$ & $\mathrm{pH}$ & $\begin{array}{l}\text { Viable } \\
\text { cells/ml }\end{array}$ & $\begin{array}{l}\text { Heat } \\
\text { stable } \\
\text { cells/ml }\end{array}$ \\
\hline$h r$ & & & & & & & & & & & & & \\
\hline 0 & 165 & 6.6 & $5.9 \times 10^{7}$ & $<10^{2}$ & 280 & 5.1 & 1.18 & $8 \times 10^{8}$ & $<10^{2}$ & 350 & 5.5 & $1.3 \times 10^{6}$ & $<10^{3}$ \\
\hline 1 & 280 & 5.3 & $1.4 \times 10^{8}$ & $<10^{2}$ & 330 & 5.4 & 1.4 & $\times 10^{8}$ & $<10^{2}$ & 350 & 5.5 & $8.7 \times 10^{5}$ & $<10^{3}$ \\
\hline 2 & 350 & 5.6 & $1.7 \times 10^{8}$ & $<10^{2}$ & & & & & & 325 & 5.6 & $9.5 \times 10^{5}$ & $<10^{3}$ \\
\hline 3 & & & & & & & & & & 500 & 8.3 & $3 \times 10^{8} 2$ & $2 \times 10^{8}$ \\
\hline
\end{tabular}

TABLE 4

Effect of pyridine carboxylic acids and versene on the germination, growth, and sporulation of Bacillus cereus at $30 \mathrm{C}$

\begin{tabular}{|c|c|c|c|c|}
\hline Compound Added & Klett Reading & $\mathrm{pH}$ & Viable Cells $/ \mathrm{ml}$ & $\begin{array}{l}\text { Heat Stable } \\
\text { Cells/ml }\end{array}$ \\
\hline None, control. & 520 & 8.0 & $6 \times 10^{7}$ & $2.8 \times 10^{8}$ \\
\hline$\alpha$-Picolinic acid $\left(1.2 \times 10^{-3} \mathrm{M}\right)$ & 320 & 5.2 & $8 \times 10^{5}$ & $<10^{2}$ \\
\hline Nicotinic acid $\left(8 \times 10^{-3} \mathrm{M}\right)$. & 510 & 8.0 & $1.9 \times 10^{8}$ & $2 \times 10^{8}$ \\
\hline Isonicotinic acid $\left(8 \times 10^{-3} \mathrm{M}\right)$. & 550 & 7.7 & $5 \times 10^{7}$ & $3 \times 10^{8}$ \\
\hline Quinolinic acid $\left(5 \times 10^{-3} \mathrm{M}\right) \ldots$ & 550 & 7.9 & $6 \times 10^{7}$ & $3 \times 10^{8}$ \\
\hline Pyridine 2,4-dicarboxylic $\left(5 \times 10^{-3} \mathrm{M}\right)$. & 550 & 7.9 & $7 \times 10^{7}$ & $3.5 \times 10^{8}$ \\
\hline Pyridine 2,5-dicarboxylic $\left(5 \times 10^{-3} \mathrm{M}\right)$ & 550 & 7.8 & $7 \times 10^{7}$ & $3.2 \times 10^{8}$ \\
\hline Dipicolinic acid $\left(5 \times 10^{-3} \mathrm{M}\right)$. & 550 & 7.8 & $3 \times 10^{8}$ & $2.7 \times 10^{8}$ \\
\hline Versene $\left(1.3 \times 10^{-3} \mathrm{M}\right) \ldots \ldots$ & 325 & 5.2 & \multicolumn{2}{|c|}{ Filamentous cells } \\
\hline$\alpha$-Picolinic acid + nicotinic acid & 325 & 5.5 & $5.6 \times 10^{5}$ & $<10^{2}$ \\
\hline$\alpha$-Picolinic acid + dipicolinic acid & 325 & 5.7 & $6.8 \times 10^{5}$ & $<10^{2}$ \\
\hline
\end{tabular}

that the former failed to sporulate, whereas the latter sporulated. It was evident that no permanent damage was done to the cells by subculturing in the presence of $\alpha$-picolinic acid.

Next the effect of time of addition of $\alpha$-picolinic acid on sporulation was studied. A large volume of medium was inoculated with an active culture and incubated at $30 \mathrm{C}$ on a shaker. At the denoted times, samples of the culture were withdrawn, $\alpha$-picolinic acid added and incubated on a shaker. After incubating for $18 \mathrm{hr}$, turbidity, $\mathrm{pH}$, viable and heat stable counts were determined. The results (table 3) compared with those of a normal culture (table 2 ) show that $\alpha$-picolinic acid inhibited sporulation only when added before the cells reached a certain age. Another interesting thing to note is that in cultures inhibited from sporulating, the turbidity and the $\mathrm{pH}$ were low. However, in these cultures a large proportion of the cells lost viability during prolonged incubation, presumably due to lysis. Greenberg and Halvorson (1955) demonstrated the presence of a specific autolytic substance, with a $\mathrm{pH}$ optimum in the range 5.0 to 5.5 in the supernatants of sporulating cultures of this organism.

The effect of $\alpha$-picolinic acid could be due to competition with nicotinic acid or chelation with some metal essential for sporulation but not for growth. To distinguish between these two possibilities, the effects on sporulation of the other pyridine monocarboxylic acids and pyridine dicarboxylic acids, with at least one carboxyl in the alpha position, were studied. None of these inhibited sporulation. Also nicotinic acid and 
TABLE 5

Effect of added minerals on the inhibition of sporulation of Bacillus cereus by $\alpha$-picolinic acid or Versene

\begin{tabular}{|c|c|c|c|}
\hline Addition & $\begin{array}{c}\text { Klett } \\
\text { Read- } \\
\text { ing }\end{array}$ & $\mathrm{pH}$ & $\begin{array}{l}\text { Heat Stable } \\
\text { Cells/ml }\end{array}$ \\
\hline$\alpha$-Picolonic only $(1.2 \times$ & & & \\
\hline $\begin{aligned}\left.10^{-3} \mathrm{M}\right) & \ldots \ldots \\
\alpha \text {-Picolinic } & +\end{aligned}$ & 325 & 5.2 & $<10^{2}$ \\
\hline $4 \mathrm{M}^{*} \ldots$ & 340 & 5.3 & $<10^{2}$ \\
\hline $\operatorname{Mn}\left(2 \times 10^{-3} \mathrm{M}\right) \ldots$ & 350 & 5.2 & $<10^{2}$ \\
\hline $\operatorname{Mg}\left(1.5 \times 10^{-3} \mathrm{M}\right)$ & 350 & 5.2 & $<10^{2}$ \\
\hline $\mathrm{Ca}\left(2 \times 10^{-3} \mathrm{M}\right) \ldots$ & 350 & 5.2 & $<10^{2}$ \\
\hline Fe $\left(2 \times 10^{-3} \mathrm{M}\right) \dagger \ldots$ & - & 5.2 & $<10^{2}$ \\
\hline $\mathrm{Cu}\left(8 \times 10^{-4} \mathrm{M}\right) \dagger \ldots$ & - & 6.0 & $<10^{2}$ \\
\hline $\mathrm{Zn}\left(7 \times 10^{-4} \mathrm{M}\right) \dagger \ldots$ & 450 & 7.6 & $4 \times 10^{7}$ \\
\hline Co $\left(8 \times 10^{-4} \mathrm{M}\right) \dagger$. & 450 & 7.6 & $3 \times 10^{7}$ \\
\hline $\mathrm{Ni}\left(8 \times 10^{-4} \mathrm{M}\right) \dagger \ldots$ & 450 & 7.6 & $4 \times 10^{7}$ \\
\hline $\mathrm{PO}_{4}\left(5 \times 10^{-3} \mathrm{M}\right) \ldots$ & 425 & 7.9 & $1.3 \times 10^{8}$ \\
\hline Yeast extract $(1 \%)$ & - & 8.4 & $2.8 \times 10^{8}$ \\
\hline Ash from yeast extract & 350 & 5.4 & $<10^{2}$ \\
\hline Versene only $(1.3 \times$ & & & \\
\hline $\left.10^{-3} \mathrm{M}\right) \ldots \ldots \ldots \ldots$ & 325 & 5.2 & $\begin{array}{l}\text { Filamen- } \\
\text { tous }\end{array}$ \\
\hline Versene $+2 \mathrm{M}$. & 450 & 7.8 & $1.8 \times 10^{8}$ \\
\hline
\end{tabular}

* $M$ represents the normal amount of minerals as contained in the medium.

$\dagger$ Inhibited germination when added in the absence of $\alpha$-picolinic acid.

dipicolinic acid were tested for their ability to reverse the effects of $\alpha$-picolinic acid. Both failed to reverse the inhibition of sporulation by $\alpha$-picolinic acid (table 4).

As it appeared that $\alpha$-picolinic acid was probably exerting its effect by chelating with some metal, the effect of Versene (ethylenediaminetetraacetic acid) on growth and sporulation of this organism was studied. When it was found that Versene also inhibited sporulation, the ability of extra minerals to reverse the inhibition by $\alpha$-picolinic acid or Versene was studied. Also phosphate, yeast extract, and ash from yeast extract were tested with $\alpha$-picolinic acid. The results (table 5) show important differences in the effects of $\alpha$-picolinic acid and Versene. Further, it should be noted that when the inhibition of sporulation was reversed, the $\mathrm{pH}$ of the culture rose to normal.

\section{DISCUSSION}

Using the technique of endotrophic sporulation with B. cereus var. mycoides, Hardwick and
Foster (1952) concluded that for an aerobe to sporulate it should have an intracellular supply of energy and an intracellular supply or "pool" of nitrogenous reserves, possibly in the form of vegetative proteins, and that there was de novo synthesis of at least part of the spore protein at the expense of vegetative cell protein. They also concluded that the ability of the cells to sporulate endotrophically was independent of the age of the culture from which the cells were harvested. Perry and Foster (1954) proved that no lysis was involved in the endotrophic sporulation of $B$. cereus var. mycoides. Unfortunately, however, not all aerobic sporeformers seem to possess this ability to sporulate endotrophically. Thus, Powell and Hunter (1953) from a study of the ability of four species of aerobic sporeformers (including a strain of B. cereus var. mycoides) to sporulate endotrophically, presented convincing evidence that in these organisms extensive lysis did occur probably providing sufficient substrates for the sporulation of other cells. Murrell (1955) obtained essentially similar results with washed vegetative cells of Bacillus subtilis. Nakada et al. (1956), working with a strain of B. cereus, showed that vegetative cells in the $\log$ phase could sporulate endotrophically, whereas those in the lag phase could not. They correlated this with the levels of intracellular free amino acids of these cells. Thus, in some organisms the ability to sporulate endotrophically seems to depend on the age of the culture from which the cells are harvested. Unfortunately, however, in this study percentage sporulation was determined by staining and as such it is hard to say if any lysis occurred during replacement sporulation or not. In our experience (H. M. Nakata, unpublished data), cells of $B$. cereus type T sporulated endotrophically only after growth ceased and not when the cells were in the actively growing phase. It thus appears that in the case of $B$. cereus there is a relation between the age of the culture and the ability of the cells to sporulate on replacement in distilled water. If any changes occur before the cells can sporulate endotrophically, it will be evident that the technique of endotrophic sporulation is not particularly suited to study these changes. It seemed to us that the best way of studying these changes during the transition from vegetative growth to sporulation of a cell would be to let it grow in a medium favorable for sporulation and inhibit this transition by the addition of compounds which would specifically inhibit sporulation. Krask (1953) has shown 
methionine sulfoxide to specifically inhibit the sporulation of a strain of $B$. subtilis grown in a glucose-glutamic acid-salts medium. Unfortunately, we have not been able to grow $B$. cereus in the same medium and when it was grown in the medium containing yeast extract, methionine sulfoxide failed to inhibit the sporulation of this organism.

From the results obtained with $\alpha$-picolinic acid, it was evident that this compound specifically inhibited the sporulation of $B$. cereus in the yeast extract-glucose-salts medium. Of all the pyridine mono- and dicarboxylic acids tested, only $\alpha$-picolinic acid possessed the ability to inhibit sporulation, the others having no detectable effect on sporulation even at high levels. Further, the fact that isonicotinic acid did not inhibit sporulation and that nicotinic acid failed to reverse the inhibition of sporulation by $\alpha$-picolinic acid suggested that the effect of $\alpha$-picolinic acid could not have been due to competition with nicotinic acid in the metabolism of the cell. The other well known property of $\alpha$-picolinic acid is its ability to chelate with metals. When the structures of the pyridine monocarboxylic acids are examined, it will be immediately apparent that only $\alpha$-picolinic acid can chelate with metals. The introduction of a second carboxyl group into the ring of $\alpha$-picolinic acid will reduce the chelating ability considerably so that the resulting pyridine dicarboxylic acids will not be able to chelate as strongly as $\alpha$-picolinic acid. This explains why the pyridine dicarboxylic acids tested failed both to inhibit sporulation and to reverse the inhibition of sporulation by $\alpha$-picolinic acid. It thus appears that $\alpha$-picolinic acid is inhibiting sporulation by chelating with some metal essential for sporulation but not for germination or growth. Lankford et al. (1957) studied the effect of chelating agents in growth initiation of Bacillus globigii. Their conclusion that the 2,4-, the 2,5-, and the 2,6-pyridine dicarboxylic acids were more stimulating than $\alpha$-picolinic acid need not be construed as being inconsistent with our findings as the metals involved in these two cases seem to be different. We found quinolinic acid to have no effect on germination, growth, or sporulation, but Lankford et al. reported it to be strongly inhibitory and suggested the cause was due to competition with nicotinic acid. However, they found no such inhibition with pyridine 3,4-dicarboxylic acid and it is not clear if isonicotinic acid would have proved inhibitory.
As it was evident that $\alpha$-picolinic acid was exerting its effect by chelating with some metal essential for sporulation, the effect of Versene also was studied. Though it did not interfere with germination, Versene did inhibit sporulation and also interfered with the process of division as the cells were filamentous. Further, important differences in the effects of $\alpha$-picolinic acid and Versene became evident when the ability of increased minerals to reverse the inhibition of sporulation was tested. While the inhibitory effect of Versene could be reversed by merely doubling the amount of minerals normally added to the medium, that of $\alpha$-picolinic acid could not be reversed even by 4 times the normal amount of minerals. Instead of increasing the content of all the minerals of the medium, the effect of increasing the content of just one mineral at a time was studied next. The effect of $\alpha$-picolinic acid could be reversed by increasing the concentration of zinc, cobalt, or nickel. However, at the same level these metal ions inhibited germination of the spores in the absence of $\alpha$-picolinic acid. Heavy metal ions were reported to inhibit the germination of spores of $B$. cereus (Murty and Halvorson, 1957b). Thus it was evident that $\alpha$-picolinic acid and the increased amount of mineral, each inhibitory when used individually, were mutually overcoming the inhibitory effects of each other by chelation when used together. The ability of phosphate to reverse the inhibition by $\alpha$-picolinic acid may also be due to competition between the two for the metal essential for sporulation, the metal chelated with $\alpha$-picolinic acid being in an unassimilable form. Different compounds may vary in their abilities to chelate with a given metal. Also the same compound may vary in its ability to chelate with different metals. The results so far obtained indicate that the metal involved may be zinc, cobalt, nickel, or some other trace metal chelating less strongly with $\alpha$-picolinic acid than these three. Lundgren and Beskid (1958) working with induced asporogenic mutants of $B$. cereus var. lacticola found that micro-amounts of zinc were essential for maximal sporulation; this element had no apparent effect upon vegetative growth.

The effect of yeast extract is very interesting. The inhibition of $\alpha$-picolinic acid can be reversed by increasing the concentration of yeast extract in the medium, but ash from the same amouni of yeast extract does not. The ability of yeast extract to reverse $\alpha$-picolinic inhibition could not have been due to its mineral content. One 
explanation of this phenomenon is that $\alpha$-picolinic acid causes a metabolic block in the biochemical changes occurring during sporulation by chelating with some essential metal. Yeast extract may reverse this inhibition by providing some organic intermediate beyond the metabolic block and thereby permitting the interrupted sequence of biochemical changes to proceed to completion.

Tinelli (1955) reported that as a culture of Bacillus megaterium entered the prespore stage, there was a marked increase in the rate of endogenous oxygen uptake, and that, after remaining at this higher rate for a short time, it decreased and became quite low as sporulation proceeded to completion. A quantitative study of the oxygen demand of an active culture of $B$. cereus at several stages during vegetative growth and sporulation made with a polarograph (Halvorson, 1957a) has revealed many interesting changes. Initially, there was an increase in the oxygen consumption per $\mathrm{ml}$ of the culture due to increase in the cell population. Later there was a rapid decrease in the oxygen consumption of the culture while the cell population remained constant. Immediately thereafter, the oxygen demand of the culture rose sharply to a higher value while there was no increase in the cell population. After remaining for a short time at this higher level, the oxygen consumption gradually decreased as sporulation proceeded to completion. Concomitant with these changes in the oxygen demand of the culture, there were significant changes in the $\mathrm{pH}$ of the culture also. Initially, the $\mathrm{pH}$ of the medium dropped gradually and then rose rapidly reaching a value higher than the starting $\mathrm{pH}$ of the medium. The valley in the $\mathrm{pH}$ curve occurred at the same time as the trough in the oxygen demand curve and corresponded with maximum growth and exhaustion of the glucose of the medium. Glucose added to the culture at this point considerably delayed sporulation (H. M. Nakata, unpublished results). The effect of time of addition of $\alpha$-picolinic acid on the sporulation of $B$. cereus becomes very meaningful in the light of these observations. $\alpha$-Picolinic acid inhibited only when added before the $\mathrm{pH}$ of the culture began to rise, having no effect if added after the $\mathrm{pH}$ of the culture began to rise. As pointed out earlier, the $\mathrm{pH}$ of an inhibited culture always remained at the low level reached during vegetative growth and on reversal of the inhibition rose to the normal level.
Turro (1891), working with $B$. anthracis, concluded that sporulation was caused by certain by-products of metabolism. Halvorson (1957a) concluded that there was a change in the enzymatic pattern of the cell during the transition from vegetative growth to sporulation of $B$. cereus. Evidence was presented to show that the early changes were fermentative resulting in the accumulation of acids. It was further concluded that the enzymes needed for the utilization of the products of fermentation were formed adaptively after maximum growth and exhaustion of glucose at which time the $\mathrm{pH}$ of the culture was at the lowest level. Larsen and Eimhjellen (1955) studying the effect of acidity on the mechanism of itaconic acid formation by Aspergillus terreus concluded that an acid environment was necessary for the formation of an essential enzyme system operating in the conversion of glucose into itaconic acid.

Hardwick and Foster (1952) reported that sporulation of the washed cells of $B$. cereus var. mycoides was inhibited by glucose. Glucose merely delayed the sporulation of $B$. cereus and some organisms have been shown to sporulate in the presence of glucose (Grelet, 1951; Powell and Strange, 1956; Ordal, 1957).

Henrici (1934) concluded that in the case of $B$. megaterium "spore formation commenced practically at the point of inflection between the logarithmic growth phase and the resting phase." The data obtained with $B$. cereus definitely point to the existence of such a point of inflection corresponding in time to maximum growth, exhaustion of glucose, and rising $\mathrm{pH}$. It is safe to conclude that the enzyme systems concerned with the utilization of the acid intermediates accumulating during vegetative growth are indispensable for successful sporulation and that they are adaptively formed at this point of inflection. $\alpha$-Picolinic acid probably inhibits sporulation by chelating with some metal essential for the synthesis of this enzyme system. Further work is in progress on the identity and fate of these acid intermediates.

\section{SUMMARY}

All the mono and some dicarboxylic acids of pyridine were tested for their effects on germination, growth, and sporulation of Bacillus cereus type T. Only $\alpha$-picolinic acid specifically inhibited sporulation without causing permanent injury to the organism when it was added before the $\mathrm{pH}$ of 
the culture began to rise. This is characterized by the accumulation of acid intermediates in the medium. The inhibition can be reversed by zinc, cobalt, nickel, phosphate, and yeast extract, but not by the ash from yeast extract. It is postulated that $\alpha$-picolinic acid interferes, by chelating with some essential metal, with the formation of an enzyme system adaptively formed between the logarithmic growth phase and the resting phase. The interference is concerned with the further metabolism of acid intermediates accumulating during vegetative growth. Yeast extract contains some organic compounds on the metabolic pathway of the above acid intermediates past the metabolic block caused by $\alpha$-picolinic acid.

\section{REFERENCES}

Buchner, H. 1890 Ueber die Ursache der Sporenbildung beim Milzbrandbacillus. Centr. Bakteriol. Parasitenk., Abt. I, Orig., 8, 1-6. Seen in Knaysi (1948).

Collier, R. E. 1957 An approach to synchronous growth for spore production in Clostridium roseum. In Spores, pp. 10-14. Edited by H. O. Halvorson. Am. Inst. Biol. Sci., Washington, D. C.

Collier, R. E. And Murty, G. G. K. 1957 The correlation of dipicolinic acid synthesis with the sporulation of Clostridium roseum. Bacteriol. Proc., 1957, 32.

Collier, R. E. ANd Nakata, H. M. 1958 Heat resistance as correlated with dipicolinic acid synthesis in spore forming bacteria. Bactteriol. Proc., 1958, 42.

Cook, R. P. 1932 Bacterial spores. Biol. Revs. Cambridge Phil. Soc., 7, 1-23.

Greenberg, R. A. and Halvorson, H. O. 1955 Studies on an autolytic substance produced by an aerobic sporeforming bacterium. J. Bacteriol., 69, 45-50.

Grelet, N. 1951 Le determinisme de la sporulation de Bacillus megatherium. I. L'effet de l'epuisement de l'aliment carbone en milieu synthetique. Ann. inst. Pasteur, 81, 430-440.

Halvorson, H. O. 1957a Rapid and simultaneous sporulation. J. Appl. Bacteriol., 20, 305-314.

Halvorson, H. O. 1957b Spores. Am. Inst. Biol. Sci., Washington, D. C.

Hardwick, W. A. and Foster, J. W. 1952 On the nature of sporogenesis in some aerobic bacteria. J. Gen. Physiol., 35, 907-927.

Harrell, W. K. 1958 Stimulation of glucose oxidation in extracts of bacterial spores by dipicolinic acid. Can. J. Microbiol., 4, 393-398.
Harrell, W. K., Dot, R. H., and Halvorson, H. O. 1957 The possible role of dipicolinic acid as a regulator of glucose oxidation in spore extracts. J. Appl. Bacteriol., 20, xiii.

HenRICI, A. T. 1934 The biology of bacteria. An introduction to general microbiology. D. C. Heath and Company, New York.

KNAYSI, G. 1948 The endospore of bacteria. Bacteriol. Rev., 12, $19-77$.

KrASK, B. J. 1953 Methionine sulfoxide and specific inhibition of sporulation in Bacillus subtilis. J. Bacteriol., 66, 374 .

Lankford, C. E., Kustoff, T. Y., and Sergeant, T. P. 1957 Chelating agents in growth initiation of Bacillus globigii. J. Bacteriol., 74, 737-748.

Larsen, H. and Eimhjellen, K. E. 1955 The mechanism of itaconic acid formation by Aspergillus terreus. I. The effect of acidity. Biochem. J., 60, 135-139.

Lundgren, D. G. AND Beskid, G. 1958 Induced asporogenic mutants of Bacillus cereus var. lacticola. Bacteriol. Proc., 1958, 46.

Murrell, W. G. 1955 The bacterial endospore, p. 46. Monograph published by the University of Sydney, Australia.

Murty, G. G. K. And Halvorson, H. O. $1957 a$ Effect of duration of heating, L-alanine, and spore concentration on the oxidation of glucose by spores of Bacillus cereus var. terminalis. J. Bacteriol., 73, 235-240.

Murty, G. G. K. and Halvorson, H. Orin. $1957 b$ Effect of enzyme inhibitors on the germination and respiration of and growth from Bacillus cereus var. terminalis spores. J. Bacteriol., 73, 230-234.

Nakada, D., Matsushiro, A., and Miwatani, T. 1956 Studies on the development of aerobic sporeforming bacteria. I. Incorporation of amino acids in the development of Bacillus cereus. Med. J. Osaka Univ., 6, 1047-1060.

Ordal, Z. J. 1957. The effect of nutritional and environmental conditions of sporulation. In Spores, p. 18-26. Edited by H. O. Halvorson. Am. Inst. Biol. Sci., Washington, D. C.

Perry, J. J. ANd Foster, J. W. 1954 Non-involvement of lysis during sporulation of Bacillus mycoides in distilled water. J. Gen. Physiol., 37, 401-409.

Powell, J. F. 1953 Isolation of dipicolinic acid (pyridine-2:6-dicarboxylic acid) from spores of Bacillus megaterium. Biochem. J., 54, 210-211.

Powell, J. F. And Hunter, J. R. 1953 Sporulation in distilled water. J. Gen. Physiol., 36, 601-606.

Powell, J. F. and Strange, R. E. 1956 Biochemical changes occurring during sporula- 
tion in Bacillus species. Biochem. J., 63, 661-668.

SChreiber, O. 1896 Ueber die physiologischen Bedingungen der endogenen Sporenbildung bei Bacillus anthracis, subtilis und tumescens. Centr. Bakteriol. Parasitenk., Abt. I, Orig., 20, 353-374. Seen in Knaysi (1948).

Stedman, R. L. 1956 Biochemical aspects of bacterial endospore formation and germination. Am. J. Pharm., 128, 84-97, 114-130.

Tinelli, R. 1955 Étude de la biochimie de la sporulation chez Bacillus megaterium. II.
Modifications biochimiques et exchanges gazeux accompagnant la sporulation provoquee par carence de glucose. Ann. inst. Pasteur, 88, 364-375.

Turro, R. 1891 Contribucion ad estudio de la esporulacion del Bacillus anthracis (Gaceta medica catalana, 1891, No. 3-4). Centr. Bakteriol. Parasitenk., Abt. I, Orig., 10, 9192. Seen in Knaysi (1948).

Williams, O. B. eT AL. 1952 Symposium on the biology of bacterial spores. Introduction. Bacteriol. Rev., 16, 89-90. 